\title{
Digital Student Agenda For Junior School During Home-Based Learning
}

\author{
Wiputra Cendana ${ }^{1}$, Yonathan Winardi², Robert H. Soesanto ${ }^{3}$ \\ wiputra.cendana@uph.edu ${ }^{1}$, yonathan.winardi@uph.edu ${ }^{2}$,robert.soesanto@uph.edu ${ }^{3}$ \\ Fakultas Ilmu Pendidikan Universitas Pelita Harapan ${ }^{1,2,3}$
}

\begin{abstract}
The purposes of this research are to investigate the needs and expectations from primary teachers of having a digital student agenda and develop a suggested model to be used during home-based learning. Open-ended questionnaire was distributed to primary teachers in a private Christian school located in Tangerang and an interview was done with the head of academic coordinator as well as with the primary curriculum coordinator to collect data. At the same time, a digital student agenda model was constructed, considering its possibilities to cover affective and spiritual aspects that allow more holistic development in the primary students lives assisted by their parents. A research and development research method was used to produce a suggested model of a digital student agenda. The results show that both primary teachers and the academic coordinator agree to have a digital student agenda that promotes more communication between teachers and parents. It is recommended this preliminary research is followed by a micro and macro-scale testing to ensure its reliability and further expanded use.
\end{abstract}

Keywords: One Primary Student Agenda, Holistic Communication With Parents, Research And Development

Received date: 30 April $2021 \quad$ Revised date: 7 September $2021 \quad$ Accepted date: 27 Januari 2022

\section{INTRODUCTION}

Online learning can be broadly defined as an educational process experienced by using the internet for teaching and learning (Singh \& Thurman, 2019). The primary key of online learning lies in its independence on students' and teachers' physical location. A physically separate space is overcome by implementing various tools for maintaining conducive interaction. Therefore, there are many terms to illustrate online learning, such as web-based learning (Subramaniam, 2013), distance learning (Uribe \& Vaughan, 2017), and the most common is e-learning (Ryan et al., 2016; Lee, 2017). The common thread that can be withdrawn from the terms is the need for internet connection and devices to keep communication running well, between parents and teachers as well as between teachers and students.

Pandemic conditions that are still ongoing until now also triggered the holding of online learning. During the outbreak, the closure of schools causes students to experience home-based learning (HBL) where they study at home. Pandemic has threatened humanity (Poon \& Peiris, 2020) and brought a substantial transition in many aspects of human life (Rahiem, 2021), including education. This outbreak brings many challenges to be tackled by the educator (Adedoyin \& Soykan, 2020). Students as learners and instructors are forced to face this unprecedented effect of the pandemic (Kelly et al., 2020). One of the issues highlighted during pandemic emergency learning is about digital communication. Several studies have found the importance of digital communication as a form of interaction between educators, students, and parents as education stakeholders (Adedoyin \& Soykan, 2020; Hidayati \& Rudiyanto, 2021). In the teaching area, digital communication is essential to boost student's confidence (Misra \& Mazelfi, 2021). Furthermore, digital communication as part of digital learning is about how those stakeholders work together to create mindful and purposeful collaboration (Bessette, 2020). This situation leads to the fact that parental engagement will potentially support the running of the HBL. Stevens \& Borup (2015) pointed out the framework of the parents' role to nurture, motivate, instruct, and monitor their children in the context of HBL. This argument is supported by Waters \& Leong (2014), who stated that parents can act as organizers who plan student work schedules and gather necessary resources. So far, recent studies tend to focus on concerning the importance of digital interaction and communication in HBL during the pandemic, mostly in the learning area between students and teachers (Kerimbayev et al., 2020; Fahmi, 2020; Angelone et al., 2020). In fact, a holistic 
learning process during the pandemic must involve parents' act, especially at the primary education stage. Early childhood education during HBL has not had adequate self-regulated learning yet. The success of HBL implementation at the primary level depends profoundly on collaboration between students, teachers, and parents (Dewi, 2020). The responsibility for learning lies more from the parents' side because parents act as teacher, motivator, and facilitator for their children's multifaceted learning needs (Hidayati \& Rudiyanto, 2021).

Early childhood education is one of the stages with the greatest complexity in acclimatizing to remote work (Santos \& de Lacerda, 2020). Sufficient communication must be well-established between parents and teachers, as parents have duties in supervising, conducting, and assisting the learning (Solekhah, 2020). In addition, recent studies revealed that various perceptions from the parents' perspective indicate how communication between teachers and parents must be established to optimize HBL implementation under the urgent situation (Schleicher, 2020; Dong et al., 2020; Garbe et al., 2020). Unfortunately, the writers observed and explored minimum communication happened in one private primary school located in Tangerang. The old student agenda (printed) the school is actually for onsite/F2F meeting. So during HBL, it needs to be modified in order to have high relevance and effectiveness as a communication tool between teacher and parents. The old agenda, not designed for HBL context, only had three parts: to do, to bring, and notes. Meanwhile, there is an opportunity for maximum communication by providing more space allocated in the new student agenda for primary: space for students to express their feeling (affective), to realize their academic progress (cognitive), and to work with their parents at home. A new student agenda can be a fast, familiar, and easy means of communication in primary level compared to any tool at present.

In addition to that gap in the field, there is still little research that nudges deeper into this issue. Therefore, the writers are called, interested, and permitted to investigate the needs and expectations from primary teachers of having a digital student agenda as a mediator to maintain communication within all stakeholders. This paper aims to describe the steps to develop a digital primary student agenda that is more holistic and reveal its on going construction for further testing on its validity and usefulness. The suggested model will be presented also to assist readers who are primary teachers for having better communication with students and their parents so maximum learning can take place in day to day HBL.

\section{LITERATURE}

The teacher's role plays a big part in students' lives. Inside the classroom, teachers act to give sufficient instructions, rules, and procedure to accommodate conducive and effective learning environment (Sanjaya \& Panggabean, 2021). It does not stop in the classroom with the teacher, but beyond that, the teacher actually should collaborate with the parents to make sure that the students are developing well in all aspects of their life. Even though some parents are incapable of spending a lot of time with their children, yet the value parents place on education can influence children's performance and achievement in school (Santrock, 2021). Therefore, it is needed for the teacher to regularly report the improvement of the students to their parents in order to keep in track with the student's development and McMillan (in Santrock, 2021) proposed a reporting strategy, which to provide parents with a weekly, biweekly, or monthly report of the student, including the student's performance on test, quizzes, projects, oral reports, as well as student's motivation, cooperation, and behaviour. This strategy will ring a bell to the parents to help their children in improving their performance. Those suggested by Santrock are very good ans suitable with the school vision and mission discussed in this paper.

Santrock added that although the current situation is not effective to communicate directly with someone, but luckily, the latest technology is getting more sophisticated and handy to everyone. There are various plaforms that can be used for classroom management, as well as communication between the teacher with the students, and the teacher with the parents. Below are the list of the platform:

1. Class Dojo (www.classdojo.com) for tracking student behavior.

2. Faronics Insight (www.faronics.com/products/insights/) for managing student computers by controlling devices and access to them.

3. Remind (www.remind.com), a communication app for contacting parents and students. 
As the learning processes in the school were challenging and encouraging the student to be more creative so that they can become a lifelong learners (Suharwoto, 2020), the links above helped the students through using laptop or gadgets. This creativity will lead them into the independent learner too.

\section{METHOD}

The research method used is research and development (R\&D) which is still in its preliminary stage. R\&D has become a popular methodology at present and in this research it starts with a careful needs analysis towards the head of school curriculum coordinator, the curriculum coordinator in one private Christian school located in Tangerang, and home room teachers in primary level. The research proposal and needs analysis instrument were prepared as well as validated by the faculty leader in January 2021. A need analysis questionnaire as research instrument was administered to the primary teachers by sharing Microsoft Forms link. The constructed needs analysis questionnaire was then piloted to two teachers from other school and concluded that the instrument is clear and valid. No statistical calculation was used as it was an open-ended questionnaire.

The choosing of the private school was conducted in purposive way, according to the principal's permission access. In addition, the purposive way can help researchers to meet the research target in addressing the research question about investigating the need analysis towards primary teachers related to digital student agenda. From the discussion with the curriculum coordinator and head of curriculum, the questionnaire was distributed to all primary home room teachers, available for 1 week to be filled, and seven primary home room teachers were willing to participate in this research.

After getting the data from the teachers' responses, those were analyzed by adopting Miles and Huberman technique (Sudiono, 2017) for collecting, extracting, and presenting the data findings. The results lead the writers to compose and revise the suggested model of a digital student agenda that is more holistic. A simple coding was used for seven participants by giving initials R1-R7.

\section{FINDINGS AND DISCUSSION}

The researchers compiled the responses and tabulated the results in table 1. It shows that $57,14 \%$ primary home room teachers still utilized the agenda for class administration during HBL. Among those teachers, there was one teacher who still maintained the use of the student agenda but did not check students towards the agenda writing completion. The teacher stated that "I still use agenda but I cannot check whether students write on their agenda book or not". Furthermore, other teachers from this category decided to use another forms to represent printed student agenda. It is exposed through some testimonies:

1. We are still doing agenda note-taking everyday. However, the students are allowed to use any books (including the agenda, if they still have one) to write the daily agenda on. (RI)

2. Still use it in the second semester. In (the) first semester, teachers uploaded the agenda in the platform (Edmodo). (R5)

3. We do not use the book (standard printed agenda from school) yet we do write agenda (R6).

However, the prolonged HBL condition implied the possibility to leave the printed format of the student agenda. Surprisingly, there were interesting facts indicating that $42.86 \%$ of teachers still used the printed one. Basically, those teachers allowed students to use any kinds of books or printed notebook according to their preference. This fact was supported from the following testimonies below. The researchers also found the teachers' tendency to neglect in checking students' preference according to the agenda style that they used.

1. Any books (or notebooks) available home (R1).

2. Teacher asks students to write in their own book in whatever book as long as it will always be available to write on and to help them have self-checking. And honestly we do not know what book they use, they could be writing on their agenda file (typing). (R6)

Moreover, the percentage of primary teachers who dismissed the printed style was greater than teachers who still maintained it. Through the given responses, it appeared that teachers have attempted digital platforms to replace the printed agenda. One teacher added that instead of using technology as student agenda representation, the parents were also provided the class weekly plan to be able to track 
Digital Student Agenda For Junior School During Home-Based Learning

(Wiputra Cendana, Yonathan Winardi, Robert H. Soesanto)

students' tasks by a Learning Management System, Edmodo. Respondents mentioned that there were two potential platforms to use as an online student agenda, namely Edmodo and Microsoft Teams.

1. We use Edmodo to list down our day-to-day agenda. We also provide the parents with weekly plan and also timeline to keep track on their tasks. (R2)

2. We post the agenda on Edmodo every day at 3 p.m (R3)

3. I use power point (and) attached (it to) the file channel on (Microsoft) Teams. (R4)

4. We made our online class agenda using Ms Word (to be uploaded) in (Microsoft) Teams (R7)

During this transition phase, $71.43 \%$ of teachers stated that the use of digital platforms as an alternative to replace the old agenda was valued as an effective, quite effective, and very effective way. There were two other teachers who were declined out from the percentage due to lack on answering the question. The following testimonies described how teachers felt the effectiveness of the new format of student agenda which they performed.

1. I consider it beneficial, because we have the online record of the agenda in the meeting chat (Microsoft Teams). (R1)

2. It is very effective so far. (R2)

3. It is quite effective. (R3)

4. It is effective to give information about today and tomorrow activities. (R4)

5. It's quite effective, since it is online, students can access at anytime and anywhere. (R7)

Table 1. Needs Analysis Results

\begin{tabular}{|c|c|c|c|}
\hline Question & Response & Frequency & Percentage (\%) \\
\hline \multirow{2}{*}{$\begin{array}{l}\text { Q1: During the HBL, do you (homeroom } \\
\text { teachers) utilize the student agenda? }\end{array}$} & 1) $\mathrm{No}$ & 3 & $42,86 \%$ \\
\hline & 2) Yes, but with another form & 4 & $57,14 \%$ \\
\hline \multirow[t]{2}{*}{$\begin{array}{l}\text { Q2: If you don't, what is used as an } \\
\text { alternative in replacing the role of the } \\
\text { printed student agenda? }\end{array}$} & $\begin{array}{l}\text { 1) Other (note) } \text { books } \\
\text { according to students' } \\
\text { preference }\end{array}$ & 3 & $42,86 \%$ \\
\hline & 2) Using LMS & 4 & $57,14 \%$ \\
\hline \multirow{5}{*}{$\begin{array}{l}\text { Q3: To what extent is the effectiveness } \\
\text { of the use of such alternatives in } \\
\text { replacing the old agenda? }\end{array}$} & 1) Very effective & 1 & $14,29 \%$ \\
\hline & 2) Quite effective & 2 & $28,57 \%$ \\
\hline & 3) Effective & 2 & $28,57 \%$ \\
\hline & 4) Not giving an answer & 1 & $14,29 \%$ \\
\hline & 5) Irrelevant answer & 1 & $14,29 \%$ \\
\hline \multirow{3}{*}{$\begin{array}{l}\text { Q4: Is there a need to have a digital } \\
\text { student agenda in the near future? }\end{array}$} & 1) No need & 1 & $14,29 \%$ \\
\hline & 2) Doubtful & 1 & $14,29 \%$ \\
\hline & 3) Yes & 5 & $71,43 \%$ \\
\hline \multirow[t]{4}{*}{$\begin{array}{l}\text { Q5: What are your expectations in } \\
\text { having a digital student agenda? }\end{array}$} & $\begin{array}{l}\text { 1) The ability to record things } \\
\text { and lessen the possibility } \\
\text { of losing tracks }\end{array}$ & 1 & $14,29 \%$ \\
\hline & $\begin{array}{l}\text { 2) User friendly for students, } \\
\text { teachers, and parents }\end{array}$ & 4 & $57,14 \%$ \\
\hline & $\begin{array}{l}\text { 3) Students can read } \\
\text { faithfully }\end{array}$ & 1 & $14,29 \%$ \\
\hline & $\begin{array}{l}\text { 4) Students can learn to type } \\
\text { faster }\end{array}$ & 1 & $14,29 \%$ \\
\hline \multirow{6}{*}{$\begin{array}{l}\text { Q6: What challenges are predicted } \\
\text { regarding the digital student agenda? }\end{array}$} & 5) Gadget exposure & 1 & $14,29 \%$ \\
\hline & 6) Adaptation & 1 & $14,29 \%$ \\
\hline & $\begin{array}{l}\text { 7) Discipline of parents and } \\
\text { students to access it }\end{array}$ & 2 & $28,57 \%$ \\
\hline & 8) Takes more time & 1 & $14,29 \%$ \\
\hline & $\begin{array}{l}\text { 9) Students' faithfulness to } \\
\text { write }\end{array}$ & 1 & $14,29 \%$ \\
\hline & 10) Internet connection & 1 & $14,29 \%$ \\
\hline
\end{tabular}

Apparently, this emergency situation did not release the need for primary teachers to digital student agenda as an essential part of communication between teachers, students, and parents. Dominantly, $71.43 \%$ of respondents admitted the need of having a digital agenda. Then, this finding was depicted into various purposes for HBL digital agenda. The majority of teachers suggested that the 
digital agenda might be user friendly for all stakeholders. Parents had different backgrounds and digital competencies at present, so that the digital agenda had to be arranged in user friendly version. Meanwhile, the other suggestions were about the practical ability to enhance students' typing skills and lessen the possibility of losing tracks. Some suggestions that pointed out the user friendly aspect are highlighted as the following responses:

1. Teachers, parents and students can access it easily. (R2)

2. Students have to write or type their agenda and teacher needs to know that parents and students have witten an read it. $(R 4)$

3. This could reach parents as well, parent can access it. (R6)

4. Students can access at anytime and anywhere. (R7)

Indeed, online activities which tended to be technology-centered, will provide some challenges in learning, including in terms of digital utilization of the agenda. Based on the written responses, the researchers view that basically, obstacles from teachers' perspective lie in the phenomenon of gadget exposure, the adaptation process to new adjustment, the consistency of accessing the agenda, and time effectiveness.

1. It takes for students to maximize the use of it and the gadget exposure will be more. (RI)

2. Adjustment. New system always need adjustment so it requires new learnings. For teachers probably okay because that's our job but for parents and students, it needs to be a better tool not just another tool. $(R 2)$

3. They (parents) do not read and tend to ignore it. (R3)

4. Discipline and parents students disciplines in using it. (R4)

5. Take more time. (R5)

6. Students' faithfulness to write. (R6)

7. Internet connection. (R7)

Considering all of these responses, the writers discussed and attempted to establish the digital student agenda as displayed in Figure 1 below. This proposed model has also been presented to the head of the curriculum and revised.



RESPONSES (From mommy/daddy)

\begin{tabular}{|c|l|}
\hline $\begin{array}{c}\text { Feedback/ } \\
\text { Questions }\end{array}$ & \\
\hline Expectation & \\
\hline Info & \\
\hline
\end{tabular}

REMINDER: "How can I pray for you today?"

Figure 1. Suggested Layout 
The suggested digital student agenda has four components. The first component is the reflection which allows students to reflect and write down their feeling about today's school during home-based learning by giving a circle on the options provided. Besides that they can write brief story of what happened regarding their emotion choice they circle. It is also optional for the home room teacher to type any story about the student as an information for the parent in that space whenever needed. The second part is responsibility which may list the things the student needs to know, do, and bring for the following day or within the week. The third part is called responses which allows parents to respond by giving feedback or questions, expressing their expecations for their child development or progress, and also giving necessary information about their child at home that the home room teacher needs to know. Last but not least, the reminder section is there to outline a brief activity or thought provoking question that can be done or discussed by parents at home after HBL session ends. This will once again give time for parents to have meaningful talk or togetherness with their child at home in the late afternoon or at night.

The finding of this preliminary research strengthens the initial purpose of having this kind of agenda, that is to gain better communication within all stakeholders in primary education. Since there were few of lack communication in learning process (Quan-juan, 2013), there is an urgent need for fulfilling the gap caused by communication barrier and limitations during the pandemic. As stated in Ozmen et al. (2016) that communication among these components, especially between teachers and parents, have been potential to perform effective counseling and guidance. The researchers consider it as a vital important factor to develop better primary students' performance during home-based learning that is still on going. Any suitable digital platform can accommodate the proposed student agenda for it is not the fancy design nor stylish features of the agenda that matter, but it is of course the content of the proposed agenda that allows clarity, collaboration, and even transformation taking place in the students' day to day home-based learning in such a difficult time like this.

\section{CONCLUSION AND RECOMMENDATION}

It can be concluded that there is a need to have and to use a digital student agenda during homebased learning in primary level with the following characteristics: user friendly, able to document, and allow students to be faithful in using it. The suggested format for the new digital student agenda agenda has four main parts: Reflection, Responsibilities, Response, and Reminder which will cover the affective and spiritual aspect during teacher-parent daily communication in primary classroom.

Recommendation for future researchers are to do conduct micro and macro-scale testing to ensure the reliability of the suggested student agenda. A Micro testing can be conducted on one class for one full week and macro testing can be conducted on three different classes for two full weeks. The junior principals need to re-ensure the determination and commitment of elementary school teachers regarding the importance of communicating with parents regularly to monitor and develop the competence of elementary school students.

\section{ACKNOWLEDGEMENT}

The authors would like to thank Lembaga Penelitian dan Pengabdian kepada Masyarakat (LPPM) Universitas Pelita Harapan that has supported and funded this research with a signed contract of P-008-FIP/II/2021.

\section{REFERENCES}

Adedoyin, O. B., \& Soykan, E. (2020). Covid-19 pandemic and online learning: The challenges and opportunities. Interactive Learning Environments, 28(1), 1-13. https://doi.org/10.1080/10494820.2020.1813180

Bessette, L. S. (2020). Digital learning during the covid-19 pandemic. The National Teaching \& Learning Forum, 29(4), 7-9. https://doi.org/10.1002/ntlf.30241

Dewi, W. A. F. (2020). Dampak covid-19 terhadap implementasi pembelajaran daring di sekolah dasar. EDUKATIF: Jurnal Ilmu Pendidikan, 2(1), 55-61. https://doi.org/10.31004/edukatif.v2i1.89 
Hidayati, N., \& Rudiyanto. (2021). Distance Learning in Early Childhood Education During Pandemic Covid-19. Proceedings of the 5th International Conference on Early Childhood Education (ICECE 2020), 538, 207-211. https://doi.org/10.2991/assehr.k.210322.045

Kelly, A., Johnston, N., \& Matthews, S. (2020). Online self-access learning support during the covid19 pandemic: An Australian university case study. Studies in Self-Access Learning Journal, 11(3), 187-198. https://doi.org/10.37237/110307

Kerimbayev, N., Nurym, N., Akramova, A., \& Abdykarimova, S. (2020). Virtual educational environment: interactive communication using LMS Moodle. Education and Information Technologies, 25(3), 1965-1982. https://doi.org/10.1007/s10639-019-10067-5

Levy, S., \& Beaulieu, R. (2003). Online distance learning among the California community colleges: Looking at the planning and implementation. American Journal of Distance Education, 17(4), 207-220. https://doi.org/10.1207/s15389286ajde1704_2

Misra, F., \& Mazelfi, I. (2021). Long-distance online learning during pandemic: The role of communication, working in group, and self- directed learning in developing student's confidence. Proceedings of the 3rd International Conference on Educational Development and Quality Assurance (ICED-QA 2020). https://www.atlantis-press.com/proceedings/iced-qa20/125952102

Ozmen, F., Akuzum, C., Zincirli, M., \& Selcuk, G. (2016). The Communication Barriers between Teachers and Parents in Primary Schools. Eurasian Journal of Educational Research, 66, 2746. https://files.eric.ed.gov/fulltext/EJ1149130.pdf\#: :text=In fulfilling an efficient education in education organizations $\% 2 \mathrm{C}$,guidance $\% 2 \mathrm{C}$ and ultimately increasing students' motivation and success

Poon, L. L., \& Peiris, M. (2020). Emergence of a novel human coronavirus threatening human health. Nature Medicine, 26(3), 317-319. https://doi.org/https://doi.org/10.1038/s41591-020-0796-5

Quan-juan, J. (2013). Strategies for the Promotion of Effective Communication between Teachers and Students. International Journal of Science and Research, 5(6), 1757-1761. https://doi.org/https://doi.org/10.21275/v5i6.nov164651

Rahiem, M. D. H. (2021). Indonesian university students' likes and dislikes about emergency remote learning during the COVID-19 pandemic. Asian Journal of University Education, 17(1), 1-18. https://doi.org/10.24191/ajue.v17i1.11525

Ryan, S., Kaufman, J., Greenhouse, J., She, R., \& Shi, J. (2016). The effectiveness of blended online learning courses at the community college level. Community College Journal of Research and Practice, 40(4), 285-298. https://doi.org/10.1080/10668926.2015.1044584

Sanjaya, H. V. C., \& Panggabean, M. S. (2021). Implementasi Prosedur, Peraturan dan Konsekuensi Kelas Untuk Meningkatkan Kedisiplinan Siswa Kelas 8. Scholaria: Jurnal Pendidikan Dan Kebudayaan, 11(1), 63-71. https://doi.org/10.24246/j.js.2021.v11.i1.p63-71

Santos, D. O., \& de Lacerda, C. M. S. (2020). The impact of covid-19 pandemic on early childhood education and comorbidities in Brazil: Challenges and perspectives. Creative Education, 11(10), 1947-1961. https://doi.org/10.4236/ce.2020.1110142

Schleicher, A. (2020). The impact of covid-19 on education: Insights from education at a glance 2020. In OECD Journal: Economic Studies. Paris: OECD Publishing. https://www.oecd.org/education/the-impact-of-covid-19-on-education-insights-education-ata-glance-2020.pdf

Singh, V., \& Thurman, A. (2019). How many ways can we define online learning? A systematic literature review of definitions of online learning (1988-2018). American Journal of Distance Education, 33(4), 289-306. https://doi.org/10.1080/08923647.2019.1663082 
Digital Student Agenda For Junior School During Home-Based Learning

(Wiputra Cendana, Yonathan Winardi, Robert H. Soesanto)

Solekhah, H. (2020). Distance learning of Indonesian early childhood education (PAUD) during the covid-19 pandemic. International Journal of Emerging Issues in Early Childhood Education, 2(2), 105-115. https://doi.org/10.31098/ijeiece.v2i2.409

Stevens, M., \& Borup, J. (2015). Parental engagement in online learning environments: A review of the literature. In Exploring Pedagogies for Diverse Learners Online (pp. 99-119). https://doi.org/10.1108/S1479-368720150000027005

Subramaniam, N. K. (2013). Web-based learning through mixed-initiative interactions: Design and implementation. Asian Association of Open Universities Journal, 8(2), 19-31. https://doi.org/10.1108/aaouj-08-02-2013-b002

Sudiono, E. (2017). Analisis kesalahan dalam menyelesaikan soal matematika materi persamaan garis lurus berasarkan analisis Newman. UNION: Jurnal Pendidikan Matematik, 5(3), 295-302. https://doi.org/https://doi.org/10.30738/.v5i3.1282

Waters, L. H., \& Leong, P. (2014). Who is teaching? New roles for teachers and parents in cyber charter schools. Journal of Technology and Teacher Education, 22(1), 33-56. https://doi.org/https://eric.ed.gov/?id=EJ1025140 